\title{
Removal Site Evaluation Report on Building 7602 at Oak Ridge National Laboratory, Oak Ridge, Tennessee
}

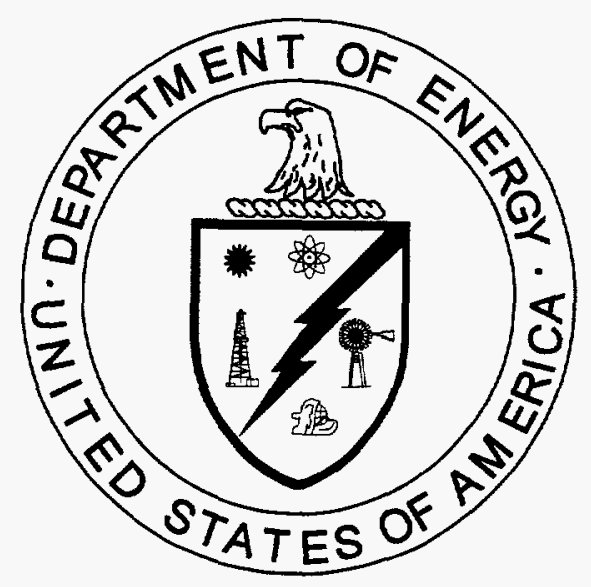

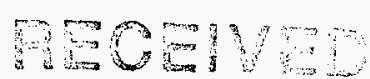

JAN 291097

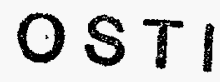

\section{DISCLAIMER}

This report was prepared as an account of work sponsored by an agency of the United States Government. Neither the United States Government nor any agency thereof, nor any of their employees, makes any warranty, express or implied, or assumes any legal liability or responsibility for the accuracy, completeness, or usefulness of any information, apparatus, product, or process disclosed, or represents that its use would not infringe privately owned rights. Reference herein to any specific commercial product, process, or service by trade name, trademark, manufacturer, or otherwise does not necessarily constitute or imply its endorsement, recommendation, or favoring by the United States Government or any agency thereof. The views and opinions of authors expressed herein do not necessarily state or reflect those of the United States Government or any agency thereof.

This document has been approved by the ORNL Technical Information Offjce for release to the public. Date: $9 / 12 / 96$ 


\section{Advanced Sciences, Inc.}

contributed to the preparation of this document and should not be considered an eligible contractor for its review.

This report has been reproduced directly from the best available copy.

Available to DOE and DOE contractors from the Office of Scientific and Technical Information, P.O. Box 62, Oak Ridge, TN 37831; prices available from 423-576-8401 (fax 423-576-2865).

Available to the public from the National Technical Information Service, U.S. Department of Commerce, 5285 Port Royal Rd., Springfield, VA 22161. 


\section{DISCLAIMER}

Portions of this document may be illegible in electronic image products. Images are produced from the best available original document. 


\section{DISCLAIMER}

This report was prepared as an account of work sponsored by an agency of the United States Government. Neither the United States Government nor any agency thereof, nor any of their employees, make any warranty, express or implied, or assumes any legal liability or responsibility for the accuracy, completeness, or usefulness of any information, apparatus, product, or process disclosed, or represents that its use would not infringe privately owned rights. Reference herein to any specific commercial product, process, or service by trade name, trademark, manufacturer, or otherwise does not necessarily constitute or imply its endorsement, recommendation, or favoring by the United States Government or any agency thereof. The views and opinions of authors expressed herein do not necessarily state or reflect those of the United States Government or any agency thereof. 


\title{
Energy Systems Environmental Restoration Program \\ Removal Site Evaluation Report on Building 7602 \\ at Oak Ridge National Laboratory, \\ Oak Ridge, Tennessee
}

Date Issued-September 1996

\author{
Prepared by \\ Advanced Sciences, Inc.

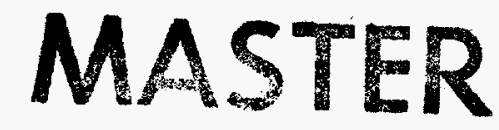 \\ Oak Ridge, Tennessee \\ under subcontract 96B-99311C \\ Prepared for the \\ U.S. Department of Energy \\ Office of Environmental Management \\ under budget and reporting code EW 70 \\ Environmental Management Activities at \\ OAK RIDGE NATIONAL LABORATORY \\ Oak Ridge, Tennessee 37831-6285 \\ managed by \\ LOCKHEED MARTIN ENERGY SYSTEMS, INC. \\ for the \\ U.S. DEPARTMENT OF ENERGY \\ under contract DE-AC05-84OR21400
}




\section{PREFACE}

This document, Removal Site Evaluation Report on Building 7602 at Oak Ridge National Laboratory, Oak Ridge, Tennessee (DOE/OR/01-1515\&D1), constitutes the final phase II remedial site evaluation of Building 7602 and was prepared in accordance with requirements under the Comprehensive Environmental Response, Compensation, and Liability Act of 1980. This work was performed under Work Breakdown Structure 1.6.6.2.1, "Oak Ridge Reservation," and Activity Data Sheet Number OR6500FT, "Oak Ridge Reservation Facility Transition Program." Publication of this document provides the Environmental Restoration Program with information necessary to evaluate whether hazardous and/or radiological contaminants in and around Building 7602 pose a substantial risk to human health or the environment and if remedial site evaluations or removal actions are required. 


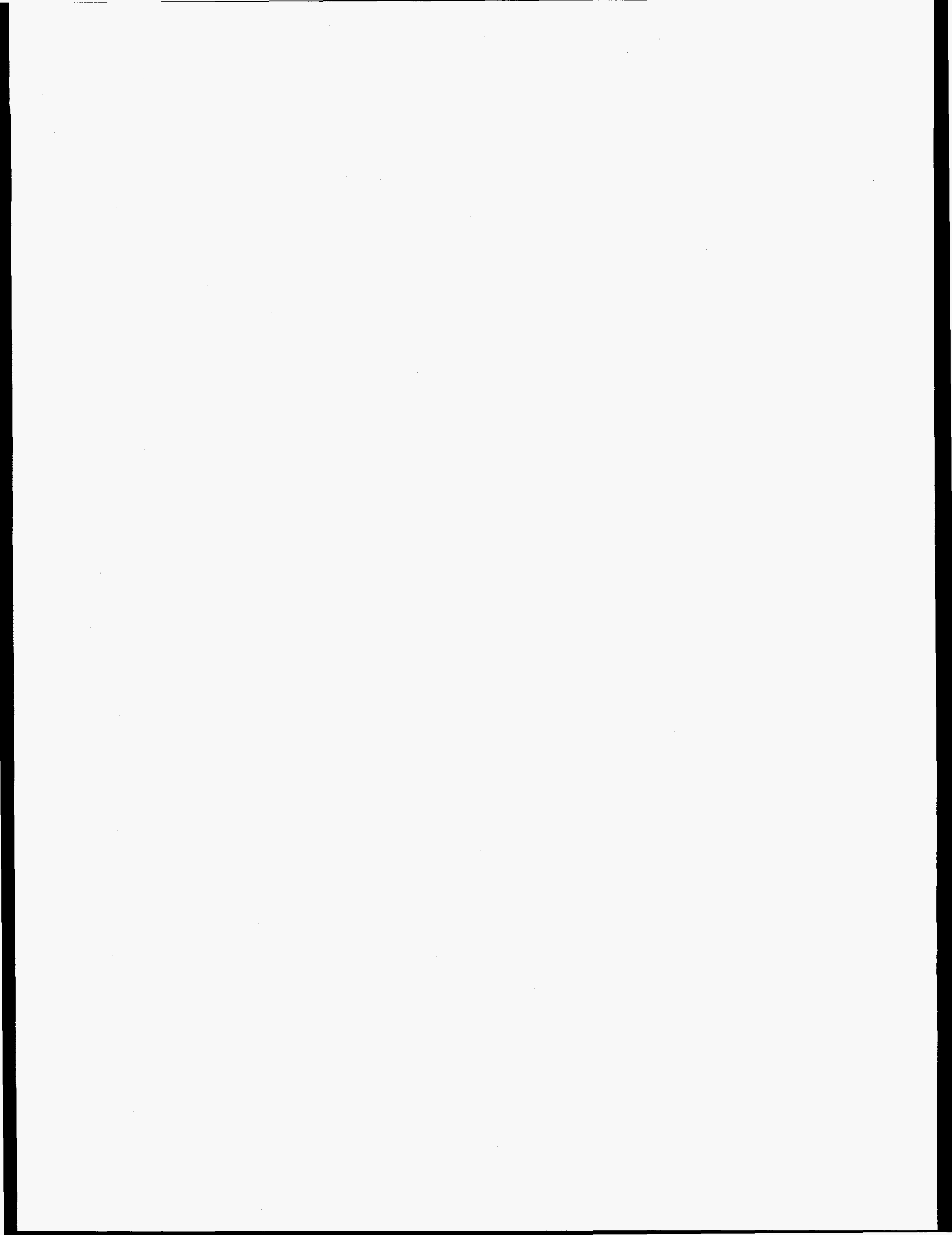




\section{CONTENTS}

PREFACE $\ldots \ldots \ldots \ldots \ldots \ldots \ldots \ldots \ldots \ldots \ldots \ldots \ldots \ldots \ldots \ldots \ldots \ldots \ldots \ldots \ldots \ldots \ldots \ldots$

ABBREVIATIONS $\ldots \ldots \ldots \ldots \ldots \ldots \ldots \ldots \ldots \ldots \ldots \ldots \ldots \ldots \ldots \ldots \ldots \ldots \ldots \ldots \ldots \ldots$

EXECUTIVE SUMMARY $\ldots \ldots \ldots \ldots \ldots \ldots \ldots \ldots \ldots \ldots \ldots \ldots \ldots \ldots \ldots \ldots \ldots \ldots$

1. INTRODUCTION $\ldots \ldots \ldots \ldots \ldots \ldots \ldots \ldots \ldots \ldots \ldots \ldots \ldots \ldots \ldots \ldots \ldots \ldots \ldots \ldots \ldots$

2. SUMMARY OF REMOVAL SITE EVALUATION $\ldots \ldots \ldots \ldots \ldots \ldots \ldots \ldots \ldots$

3. BUILDING 7602 INFORMATION FORM $\ldots \ldots \ldots \ldots \ldots \ldots \ldots \ldots \ldots \ldots \ldots \ldots$ 


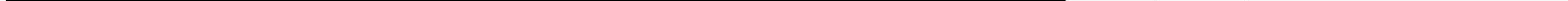




\section{ABBREVIATIONS}

$\mathrm{ACM}$

CFR

D\&D

DOE

EGCR

ER

HAZMAT

HEPA

HRFDP

LBP

LMES

ORNL

PCB

PUREX

RAD

RCRA

RmSE

RPSC

S\&M

TCLP

TSCA

WAG asbestos-containing material

Code of Federal Regulations

Decontamination and Decommissioning

U.S. Department of Energy

Experimental Gas-Cooled Reactor

Environmental Restoration (Program)

hazardous material

high-efficiency particulate air (filter)

High Ranking Facilities Deactivation Project

lead-based paint

Lockheed Martin Energy Systems, Inc.

Oak Ridge National Laboratory

polychlorinated biphenyl

plutonium and uranium extraction process

radiologic

Resource Conservation and Recovery Act

removal site evaluation

Robotics and Process Systems Complex

surveillance and maintenance

Toxicity Characteristic Leaching Procedúre

Toxic Substances Control Act

waste area grouping 



\section{EXECUTIVE SUMMARY}

This removal site evaluation report for Building 7602 at Oak Ridge National Laboratory was prepared to provide the Environmental Restoration Program with information necessary to evaluate whether hazardous and/or radiological contaminants in and around the facility pose a substantial risk to human health or the environment (i.e., a high probability of adverse effects) and whether remedial site evaluations or removal actions are, therefore, required. The scope of the project included (1) a search for, and review of, readily available historical records regarding operations and use of the facility (including hazardous substance usage and existing contamination); (2) interviews with facility personnel concerning current and past practices; and (3) a brief walk-through to visually inspect the facility and identify existing hazard areas requiring maintenance actions, removal actions, or remedial evaluation.

The results of the removal site evaluation indicate that areas associated with Building 7602 pose no imminent hazards requiring maintenance actions. Adequate engineering and administrative controls are in place and enforced within the facility to ensure worker and environmental protection. Current actions that are being taken to prevent further release of contamination and ensure worker safety within Building 7602 are considered adequate untii decontamination and decommissioning activities begin.

Given the current status and condition of Building 7602, this removal site evaluation is considered complete and terminated. 


\section{INTRODUCTION}

A removal site evaluation is required by the regulators for all facilities in the Nuclear Material and Facility Stabilization (EM-60) Program included in Appendix C of the Federal Facility Agreement. Between May 6 and May 16, 1996, a removal site evaluation was conducted on Building 7602, also known as the Integrated Process Demonstration Facility. The scope of the project included (1) a search for, and review of, readily available historical records regarding operations and use of the facility (including hazardous substance usage and existing contamination); (2) interviews with facility personnel concerning current and past practices; and (3) a brief walkthrough to visually inspect the facility and identify existing hazard areas requiring maintenance actions, removal actions, or remedial evaluation. The results of the evaluation are summarized in Sect. 2 of this report, and the more detailed information form is presented in Sect. 3. 


\section{SUMMARY OF REMOVAL SITE EVALUATION}

Building 7602 is currently in a deactivated, standby mode awaiting entry into the Decontamination and Decommissioning (D\&D) Program. Currently, no operations other than surveillance and maintenance (S\&M) are ongoing in this building. The building is accessed periodically by personnel in order to conduct various S\&M activities; otherwise, the building remains secured from public access.

During the removal site evaluation, no imminent hazard areas requiring maintenance actions were identified inside or outside Building 7602. Radiologic (RAD) hazard areas and asbestoscontaining materials (ACMs) are marked and isolated as necessary to ensure worker safety and to prevent inadvertent release within the facility. In addition, a combination of engineering and administrative controls are in place and enforced within the facility for worker and environmental protection. Current actions being taken to prevent further release of contamination and ensure worker safety within Building 7602 are considered adequate until D\&D activities begin.

Given the current status and condition of Building 7602, this removal site evaluation is considered complete and terminated according to the requirements for removal site evaluation termination set forth in 40 CFR $300.410(\mathrm{e})$. 
3. BUILDING 7602 INFORMATION FORM 

ORNL FACILITY RmSE INFORMATION FORM

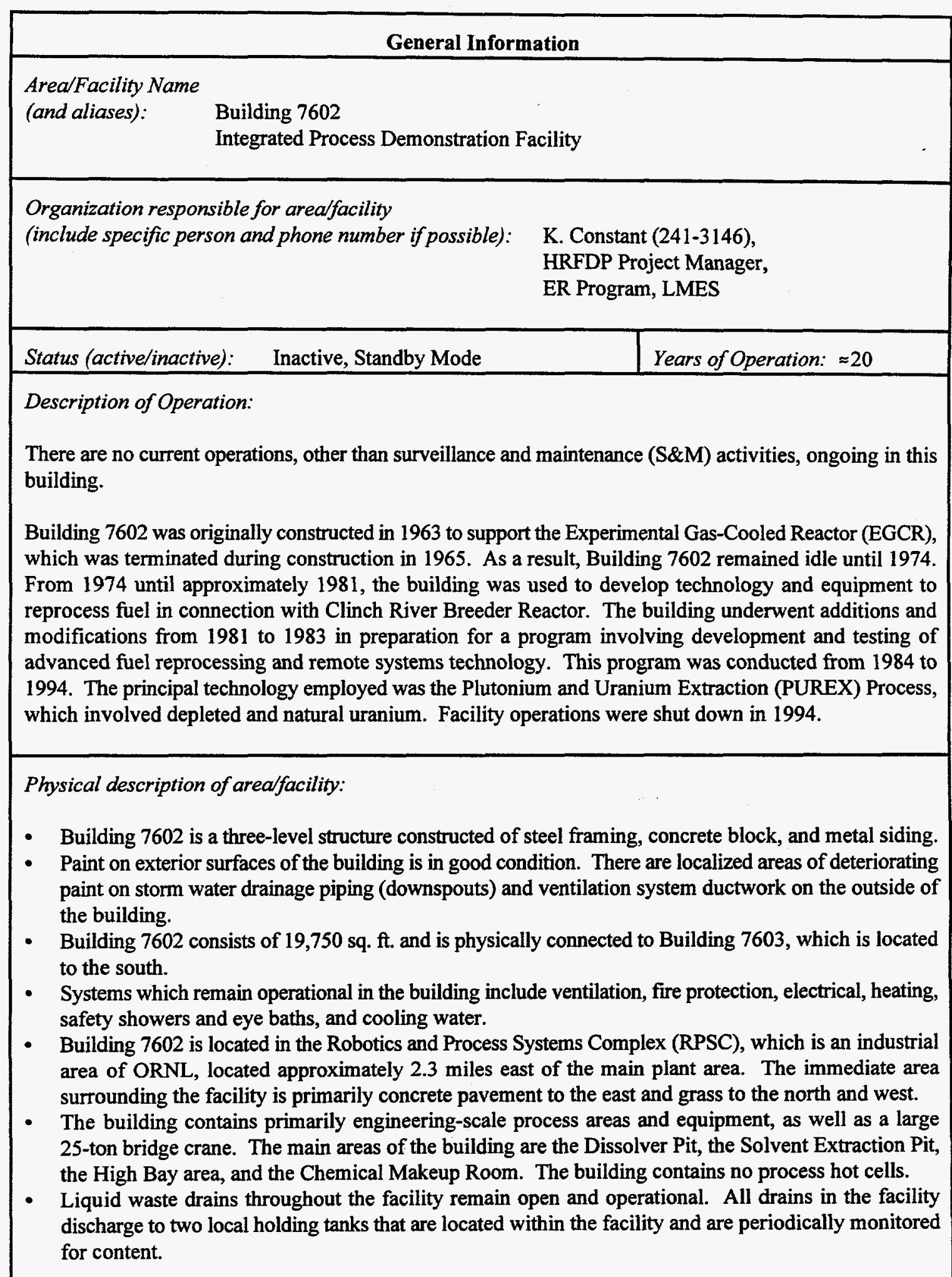


Physical description of arealfacility (continued):

- Generally, the interior of the building is in good condition. Asbestos-containing material (ACM) and radiation (RAD) hazard areas are posted and/or labeled as appropriate. No PCB items were identified to be present in the facility. Painted surfaces throughout the facility are in good condition except for the Chemical Makeup Room, where there are areas of localized deterioration on painted walls, equipment, and piping.

- The draw of the ventilation system within the building keeps the interior under slight negative pressure relative to the atmosphere. However, the building is not sealed.

- A building space diagram is attached to this form, showing the locations of the various process areas.

\section{Release Information}

Description of release, or threatened release, and source:

The principal process materials used in Building 7602 were depleted and natural uranium, nitric acid, and organic solution (dodecane, a normal paraffin hydrocarbon, and tributyl phosphate).

A small amount of residual radiologic surface contamination exists in areas of the facility as a result of historical operations. The contamination exists primarily on facility surfaces and inside process equipment (vessels, tanks, piping, ventilation ducts, etc.). This contamination has accumulated from various activities throughout the operating history of the facility and, therefore, cannot be attributed to a single release episode. The presence of RAD contamination at existing levels within the facility is not considered a significant hazard in its current state.

The Dissolver Pit housed process equipment used for dissolving uranium from fuel rods. No waste or hazardous substances were intentionally collected in this pit. In addition, no inadvertent releases of such substances were experienced in this pit.

The Solvent Extraction Pit housed process equipment used in the solvent extraction process. Various solvents were extracted from materials and reused in processes within the facility during operations. The pit provided secondary containment in the event of a spill. According to facility personnel and available records, no spills of hazardous substances were experienced in this pit. Upon deactivation, solvents remaining in the facility were drummed and sent to the TSCA incinerator at the K-25 Site to be used as blending material for the burners.

Hazardous materials (HAZMATs), listed above, were reportedly used in large quantities (i.e., greater than 5 gal or $100 \mathrm{lbs}$ ) during facility operations. Currently, all HAZMATs have been removed from the facility with the exception of a few miscellaneous items used in S\&M activities. According to available spill/release records and facility personnel interviews, no significant HAZMAT spills (i.e., spills having the potential to adversely affect human health and/or the environment) have been reported for this building. No current conditions were identified as presenting a potential for a significant HAZMAT release.

Hazardous substances present:

Hazardous substances remaining in Building 7602 consist mainly of residual RAD surface contamination. Areas of RAD contamination are associated primarily with facility surfaces and process equipment. No PCB items or HAZMATs of any significance were identified to be present in the facility. 
Estimate (if possible) of quantities of hazardous substances that have been released and that could be released:

The following represents the estimated quantities of substances currently existing in the facility. Radiologic surface contamination has accumulated from a legacy of many different activities and processes and cannot be attributed to a single release episode. It is only possible to quantify release amounts from contamination that currently exists in the facility and/or has been historically documented from past activities.

$\approx 10 \mathrm{~kg}$ uranium in the form of residual surface contamination.

(Quantity estimate obtained from Building 7602 deactivation report.)

Other pollutants or contaminants:

ACM, primarily in the form of thermal system insulation, has been confirmed present in this building. ACM observed is in good condition and poses no immediate health threat. On the basis of the age of the facility, interior and exterior painted surfaces are assumed to be lead containing. Verification samples are taken by ORNL Lead Management Program personnel on an "as-needed" basis to confirm the presence of lead in the paint (i.e., when work activities will disturb the paint or when paint is found to be deteriorating and poses a health or environmental threat). Observed interior painted surfaces are in good condition throughout the majority of the facility and pose no immediate health threat. However, paint on the walls, piping, and equipment in the Chemical Makeup Room is significantly deteriorated in areas. On the basis of the inactive status and level of activity in this building, the peeling paint in this room does not pose a significant threat.

\section{Groundwater}

Are there any suspected impacts to groundwater? If yes, please describe. Include any impacts to drinking water sources.

Building 7602 is located in Waste Area Grouping (WAG) 18 at ORNL. The building houses a closed-loop drainage system consisting of two waste storage tanks (1477- and 1266-gallon tanks) located in the basement. All building drainage systems currently discharge to these tanks. A third tank, currently empty and isolated from Building 7602, was historically used to collect process waste water from the building. This 13,000-gallon tank (designated F-15) is located underground approximately 50 yd northwest of the building. Process waste water was monitored prior to discharge to Tank F-15. Contaminated waste water was diverted to storage tanks within the facility for proper treatment and disposal, and uncontaminated waste water was discharged to Tank F-15.

No reasonable evidence was identified during this $\mathrm{RmSE}$ to suggest that historical processes and operations associated with Building 7602 have adversely impacted groundwater in WAG 18 . In addition, no conditions threatening to groundwater were identified to be currently associated with Building 7602 . 


\section{Surface Water}

Are there any suspected impacts to surface water? If yes, please describe. Also describe the most likely surface water migration route(s), if applicable. Include any impacts to drinking water sources.

To minimize the potential for off-site migration of contamination, storm water (from surface runoff and storm water drainage system) from the RPSC area is collected in two local retention ponds (191-West and 291-North). Quarterly monitoring of these ponds includes analysis for oils, grease, and RAD (beta) contamination. As a result, it is unlikely that surface water in the area of Building 7602 has been or could be directly impacted by contamination migration via surface pathways.

No existing immediate threat to surface water was identified to be currently associated with Building 7602 given the current status, condition, and types of activities associated with the building.

\section{Air}

Are there any suspected impacts due to air emissions? If yes, please describe.

Air in Building 7602 is controlled by the building ventilation system, which exhausts the air through a high efficiency particulate air (HEPA) filter bank before it is discharged to the atmosphere through a scrubber stack adjacent to the domed reactor building (Bldg. 7600). The draw of the ventilation system creates a slight negative pressure within Building 7602; however, the building is not sealed. Continuous air monitors within the facility have indicated that indoor air quality has been impacted in the past by airborne particulate matter released from areas of dried uranyl nitrate surface contamination. These areas have been mitigated and no longer present a immediate hazard to indoor air quality.

A potential does exist for impact to indoor air quality as a result of the presence of ACM and assumed leadbased paint (LBP) in the event that these materials are disturbed. The ACM and assumed LBP remaining in the building are not considered to be immediate threats to indoor quality in their current state.

Soil

Are there any suspected impacts to soil? If yes, please describe.

No reasonable evidence was identified during this $\mathrm{RmSE}$ to suggest that historical processes and operations associated with Building 7602 have adversely impacted soils in WAG 18.

There is, however, an existing potential for areas of soil adjacent to the facility to be impacted from lead if, in fact, exterior paint is found to be lead containing. Deteriorating paint could dislodge from the surface and fall to the soil below. With the exception of a few localized areas of deterioration on roof drainage piping and ductwork, exterior paint was observed to be good condition and does not pose an significant threat in its current state. 


\begin{abstract}
Release Beyond Facility or Reservation Boundaries
Has or will the release migrate beyond the boundaries of the facility or reservation? If yes, please describe (including possible human or environmental receptors).

The following are considered potential scenarios where radiologic contamination could migrate beyond the facility or reservation boundaries:

- A person becomes inadvertently contaminated from residual surface contamination and leaves the facility/reservation undetected.

- Catastrophic failure of the building or contaminated equipment.

There is also a potential for assumed lead-containing paint that peels off the building to be carried away from the facility and off-site with surface runoff during a rain event; however, this potential is minimized by the presence of the storm water retention ponds that are in place. Although these potentials exist, they are considered slight and unlikely due to the current status and condition of the facility and the engineering and administrative controls that are in place to protect again such an event.
\end{abstract}

\title{
Worker Safety
}

Could the release pose a threat to workers? If yes, please describe.

Radiologically contaminated areas are isolated and well marked. Good radiation practices and standard operating procedures governing activities within the facility are enforced for worker safety. Personnel exiting the facility are required to "frisk" themselves to detect the presence of RAD contamination. Monitors and alarms are in place to detect any radioactive release within the building. ACM is appropriately labeled. The building remains secured and access is controlled. However, even with these safeguards in place, a potential threat to workers exists if safety measures are overlooked. This potential is not considered significant given the current status and level of activity of the building.

\section{Environmental Receptors}

Does the release pose a potential threat to environmental receptors? If yes, please describe. Include natural resources impacts.

No other existing conditions posing an immediate significant threat to environmental receptors, including natural resources, were identified to be currently associated with Building 7602 .

\section{Mitigation}

What action(s) might be taken to abate/prevent release or impacts from release?

- Continued utilization and enforcement of engineering and administrative controls that are currently in place to protect workers and monitor conditions and activities in the building.

- Continue S\&M activities per Procedure DIV-SM-CKS-018, "Routine Surveillance and Maintenance Procedure for Building 7602". 
What actions are currently being taken to abate/prevent release or impacts from release?

Engineering and administrative controls are in place to control access to the facility and contaminated areas, and to monitor conditions and activities within the facility for worker and environmental protection. Warning signs and labels are posted throughout the facility to indicate RAD and ACM hazard areas. Standard operating procedures are in place for building access and S\&M activities to protect against inadvertent contact and disturbance of contaminated areas and materials. The building is monitored periodically by ORNL health physics personnel for areas of RAD contamination. Personnel are "frisked" upon exit of the facility to detect the presence of radiologic contamination. The building is currently deactivated and in S\&M status, awaiting entry into the Decontamination and Decommissioning (D\&D) Program. The ventilation, fire protection, electrical, steam heating, safety shower and eye bath, and drainage systems remain operational to maintain current conditions in the facility and to prevent inadvertent contamination discharge. The building is inspected periodically for structural changes and degradation, which include any cracking, failure, or deterioration of the facility and/or equipment that may allow contamination to be released.

Current actions being taken to prevent further release and ensure worker safety in Building 7602 are considered adequate until $D \& D$ activities begin.

\section{Other Environmental Authorities}

Is the release or threatened release potentially subject to other environmental statutory actions? If yes, please explain.

If paint associated with the facility is found to be lead-containing and samples fail the Toxicity Characteristic Leaching Procedure (TCLP) analysis, the building could qualify as a hazardous waste generator point under the Resource Conservation and Recovery Act (RCRA).

\section{Maintenance Actions}

Are maintenance actions necessary to eliminate potential threats to human health and the environment? If so, explain.

No existing hazards requiring maintenance actions were identified to be associated with Building 7602 .

\section{Removal Actions}

Are Removal Actions necessary to eliminate immediate threats to human health and the environment? If so, explain.

No imminent hazards requiring removal actions per 40 CFR 300.415 were identified to be currently associated with Building 7602 .

\section{Remedial Site Evaluation}

\section{Is a Remedial Site Evaluation needed?}

On the basis of the age of the facility, painted surfaces are assumed to contain lead. Samples of the paint should be taken and analyzed to verify the presence of lead prior to conducting any S\&M or D\&D activities that may disturb these assumed areas. 


\begin{abstract}
No Further Investigation
Is a finding of No Further Investigation appropriate? Please explain.

A finding of No Further Investigation implies that a facility or area is free from hazardous substances or contaminants that may threaten human health and the environment. Because Building 7602 contains substances and materials that may become threatening if not properly controlled, handled, and managed during the S\&M cycle, a finding of No Further Investigation is inappropriate in this case.
\end{abstract}

\title{
Additional Comments
}

The following documents and databases were referenced for historical and hazard information related to Building 7602:

- Work Plan for the High Ranking Facilities Deactivation Project at Oak Ridge National Laboratory, Document No. ORNL/ER-322.

- Building 7602 Occurrence Reports.

- Deactivation of Building 7602, ORNL/TM-13093.

- ORNL Hazardous Material Information System Database.

- ORNL PCB Inventory Database.

- EM60 Facility Inventory and Assessment Database.

The following personnel and offices were contacted and provided historical and current use/condition information for Building 7602:

- Mr. Terry Collins, Facility Operations Specialist/Facility Manager, Building 7602.

- Mr. Jeff Barnett, Facility Operations Technologist, Building 7602.

- Ms. Swati Wilson, Manager, ORNL Lead Management Program.

- Mr. Nathan Dunn, Hazardous Material Information System Office.

- Mr. Jade Thomas, ORNL Environmental Compliance Office.

The RmSE of this facility was conducted for LMES under contract by:

Advanced Sciences, Inc.

800 Oak Ridge Turnpike, Suite C-102

Oak Ridge, TN

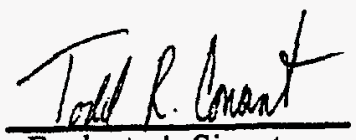

Evaluator's Signature 


\section{DISTRIBUTION}

1. L. V. Asplund

2. T. W. Burwinkle

3. K. W. Cook

4. R. E. Eversole

5. L. L. Kaiser

6-8. D. M. Matteo (3)

9. P. T. Owen

10. L. D. Owens

11. P. A. Schrandt

12. Central Research Library

13. ER Central Doc. Mgmt. Center-RC

14. R. L. Nace, Team Leader, Fernald/Ohio Team, Office of Environmental Restoration, U.S. Department of Energy, Cloverleaf Building, EM-425, 19901 Germantown Road, Germantown, MD 20874

15. J. W. Wagoner II, Team Leader, Portsmouth/Paducah/Weldon Spring Team, Office of Environmental Restoration, U.S. Department of Energy, Cloverleaf Building, EM-424, 19901 Germantown Road, Germantown, MD 20874

16. V. F. Boston, DOE Oak Ridge Operations Office, P.O. Box 2001, Oak Ridge, TN 37831-8541

17-18. R. C. Sleeman, Director, Environmental Restoration Division, DOE Oak Ridge Operations Office, P.O. Box 2001, Oak Ridge, TN 37831-8541 (2)

19-20. Office of Scientific and Technical Information, P.O. Box 62, Oak Ridge, TN 37831 (2)

21. T. R. Conant, Advanced Sciences, Inc., 800 Oak Ridge Turnpike, Suite C-102, Oak Ridge, TN 37830-6927 